\title{
ANALYSIS OF TRENDS AND MANAGEMENT PATTERN OF EDUCATIONAL AID IN NEPAL
}

Ananta Dahal*

\begin{abstract}
s
This research article, "Analysis of Trends and Management Pattern of Educational Aid in Nepal: An Empirical Analysis" aims to analyze the trends and management pattern of education aid in Nepal. Aid is the essential means to remove the bottleneck of development in Nepal. Since 1952 AD international donors have been supporting education sector reforms in Nepal with individual basis. Aid program Education for All (EFA), (2004-2009 AD) was established with donors and Nepal Government Joint Financing Agreement (JFA) for the school education reform. Then after, EFA (2001-2015) established education aid for the reform of primary education in Nepal. This research used the secondary data from the different sources of information and used the descriptive research design for data analysis. The researchers concluded that the educational aid trend is in increasing way in each year, only effective management will fulfill the target and increase the effectiveness of the educational aid in the context of Nepal.
\end{abstract}

Keywords: trend, management, pattern, educational, aid

\section{Background of the Study}

In a rational world, aid is still essential means to remove the bottlenecks of development in Nepal. When we argue the pros and cons of aid, it is found that aid in many cases has been key in boosting developing countries' growth" (Powell, 2007). Meanwhile, many researchers and practitioners have been discussing about the success and failure of aid but accept the essentiality of aid in Nepal as the country's financial situation is fragile (World Bank, 2005).

According to Bhattarai (2009), education indeed plays very crucial rolefor stable socioeconomic development. Considering the importance of education towards stable and sustainable development, bilateral and multilateral development partners are supporting us in education. At the same time, we have a challenge of effective use of available aid. There are, however, questions and claims whether we have been using the aid effectively.

Donors have been supporting education in Nepal since 1952. In initial stage, individual donors funded through individual projects but since EFA 2004-2009 aid came by donor pool system which became possible by Joint Financing Agreement (JFA) launched by

*Mr. Dahal is a PhD scholar and assistant professor of economics, Patan Multiple Campus, TU, Nepal 
agreement between development partners and Nepal. The study of aid effectiveness would certainly take study into difficult apparatus because it is very vague and complex phenomena to cover at a time. Delimiting the study only in Education For All (EFA) 20012015 it is limited the study area and even focusing on a main question "How effective has been aid in primary education in Nepal?” undoubtedly made the study more concrete.

Many donor countries have prepared explicit commitments to scale up aid significance in due course of time. "Five of the twenty-two Donors Agency Countries (DAC) member countries have already increased ODA to the level, exceeding the UN target of 0.7 percent of GNI (Bourguignon \&Leipziger, 2006). Similarly, The EU has also promised to increase aid to developing countries from 0.35 percent of GNI in 2004 to 0.7 percent by 2015, with an interim target of 0.56 percent by 2010. Moreover, six EU member countries announced commitments to attain the 0.7 percent (Hudson, 2007; The World Bank, 2006; United Nations, 2003).

It is not our concern whether donor countries are fulfilling their commitment to UN or not, but in the rational world, it is the rightof every developing country to receive aid as per the international development strategy for the Second United Nations Development Decade (USAID, 2004).

We know, present is the result of past and future is determined by our present activities. No one can escape from past deeds. The developed countries are developed now as they could exploit the resources from other developing countries and make best use of them. In fact, the prosperity of developing nations means the prosperity of developed countries too because the progress, peace and prosperity of each and every country interlink each other. For instance, in the global village, developed countries have been exploiting the resources of developing countries for industrialization not only creating harmful effects, but also obscuring them from development and for that they paid tax or compensate through aid (Godoy, 2009). Nevertheless, it is the responsibility of both recipients and donor countries to make the effective use of this aid. Hence, the central theme of the study is to explore how effective has been the use of aid we have been getting in Nepal with reference to aid effectiveness principles stipulated in Paris Declaration.

The aid to developing nations by making good economic policy, financing new development-friendly technologies, and opening up labor markets could have more significant benefits for the donor countries themselves (Birdsall, 2005). Hence, it is not only the receiver who is trying to make effective use of what is given but also the donor seeking to invest in the productive areas for high rate of returns. So, it is high time to direct the attention of the world's wealthiest nations to other ways of helping the country like Nepal with best effort. 
The effectiveness of aid is the interest of both recipient and donor countries; however, to make it more efficient by fulfilling the targeted goal with available aid is a very difficult task. In Nepal, aid is an immense part of total investment and important component in the development process. So, the success of aid utilization depends on the domestic efforts and the mutual relationship with donor countries. However, the study reveals that Nepal has been receiving aid in its good amount, but whereabouts of the investment has still been mystery. Hence the concern of effective management of the aid we receive in education is the essence of the study. So, for the effective use of aid and its management, national commitment, policies and long term effective planning are essential.

\section{Objective of the Study}

The purpose of this study is to analyze trends and management pattern of educational aid in Nepal and its effectiveness in primary sub-sectors by focusing on the EFA 2001-2015.

\section{RESEARCH METHODOLOGY}

Rigorous research designs are important because they guide the methods decisions that researchers must make during their studies and set the logic by which they make interpretations at the end of studies. This research is based on qualitative methods as approach for a study and descriptive research design has been used. This analysis of the study is done with the help of secondary data. The required data were collected from various sources like Ministry of Education, Ministry of Finance, National Planning commission, The World Bank, Asian Development and various websites.

The most commonly used secondary data are documents, physical data, and archived research data. It is different from primary data as it involves the utilization of existing data collected for the purposes of a prior study. The secondary analysis of the primary data enhances the trustworthiness of original work. Collected data had tabulated to meet the requirement of the study. While shaping the data in the tabulated from, proper attention is given not to let the chances of error. Descriptive and analytical method has been used in this qualitative research. The trends and management modalities pattern of aid in Nepal explore based on the EFA program (2001-2015) from the help of the following subheading of the data analysis.

\section{Trend of Aid Volume}

It is rather complicated to trace out the history of aid in education in Nepal. However, modern education was indeed the result of the aid in Nepal. A good number of schools for the basic and primary education were established in 1980s with the commencement of Basic and Primary Education Project which was largely supported by development partners. But here my concern is to focus on EFA covering five years' duration from (2001-2015) for 
analyzing trends in flow of aid in education. While providing the trends for EFA, it may be interesting to see the nature trends concerning BPEP and SSRP as well. Donors supported in the form of basket funding and direct funding (MOE, 2003; Udenrigsministeriet, 2003).

Figure.1. Funding Shared by Government and DPs in BPEP II, EFA and SSR (In million US\$)

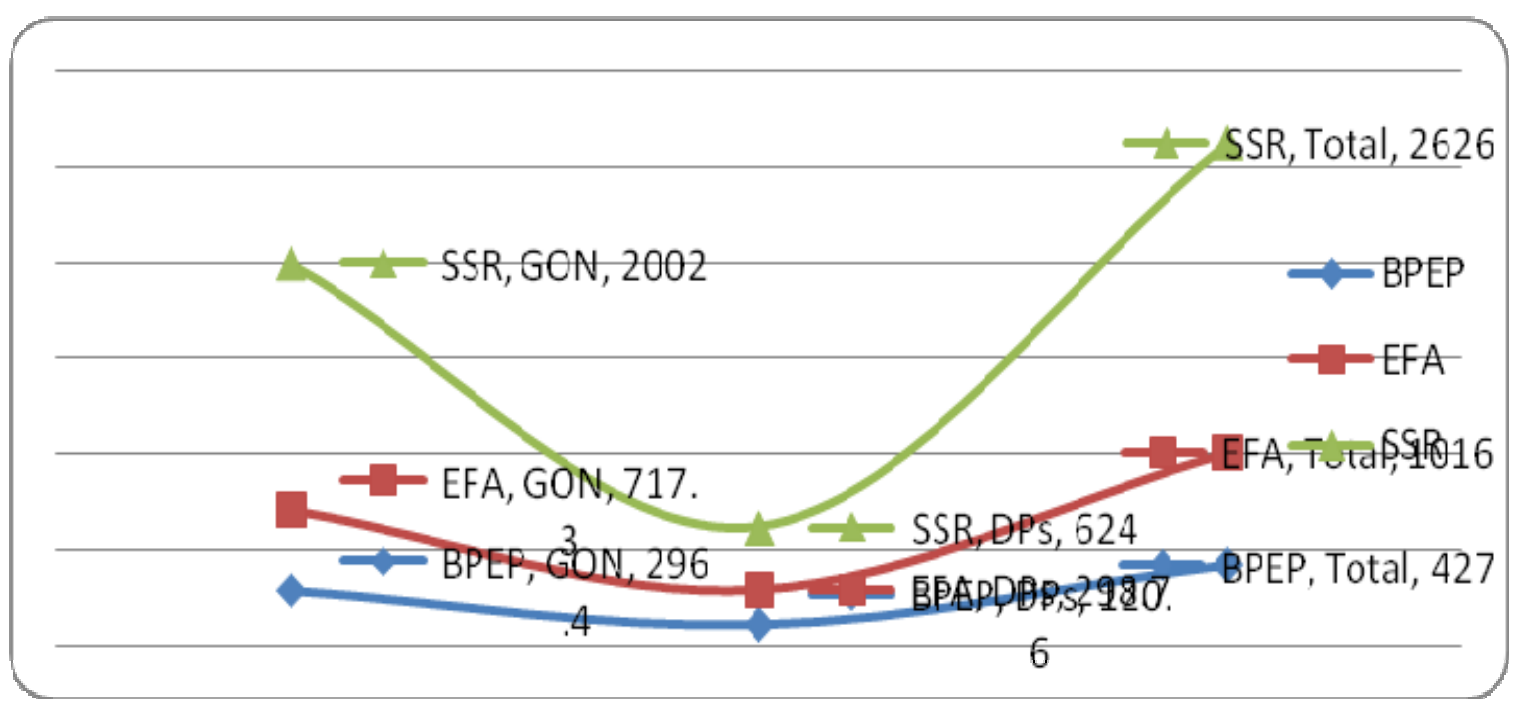

Source: Researchers Calculation, 2018

BPEP II, EFA and SSR each began as a five years' project. In BPEP II, the total expenses were US\$ 427 million and development partners’ support was US\$121 million (28 percent). Regarding EFA, the total expenses was US\$ 1016 million and development partners' support was US\$ 299 million (29.5 percent). Similarly, School Sector Reform (SSR) is being initiated as a five years' program and a total expected expense is US\$ 2626 and development partners have pledged to support US\$ 624 million (24 percent). The figure 1 shows that the trend of the flow of aid seems to have been increasing from BPEP to EFA and to SSR.

The five years' long EFA program was funded by government and development partners; where the government's share was 70.5 percent whereas the development partners' share was 29.5 percent. This five yearlong fund flow was divided into year wise and presented in a graph below:

\section{Figure.2. Total Funding for EFA (in percentage)}






Source: Researcher Calculation, 2018

Figure 2 shows year wise fund flow by the government and development partners reflected that gradually development partners' support was increased. In 2004/05, development partners' support was 25 percent but in 2008/09, the development partners' support was 36 percent.

According to a donor representative, one of research participants confirms the increasing trend of aid with the observation, the aid flow from BPEP to EFA and to SSR is significantly increasing and this is good in the context of Nepal.

A senior government official agreed that in context like Nepal's where massive efforts are undertaken for rapid acceleration of primary and basic education, increased volume of aid is a necessity. It is satisfactory that the volume of aid seems to be on the increasing trend. Meanwhile, the respondent also observed, "Not only the volume of the aid is significant but how the aid managed into a package and presented matters a lot". Actually, complexity management perspective in the speedily changing context accredits to the need for adopting holistic approach in the sense that it is not only the relationship between aid and program objectives but the whole lot that is involved in the entire process of aid utilization (Dann \& Barclay, 2006; Juarrero 2006; Serrat, 2009).

\section{Aid Management Modalities}

The nature and form of aid modality contributes to the effective management of aid. Therefore, contextualizing aid management modality is pertinent for the effective use of aid. 


\section{Donor Driven vs. Needs Driven}

Whether aid should be donor-driven or needs driven is a critical issue. It is high time that we should make fundamental changes in aid practices which secures our strong position in determining the strategies for aid acquisition and utilization.

\section{Aid Paradigm vs. Local Context}

In general, the aid paradigm engulfs the global context of aid effectiveness criteria set in accord to the global scenario which fails to undertake the elements influencing the local contexts of the recipient countries like Nepal. This blanket-concept paradigm is thus may not be able to fit into the aid paradigm required for the local context of Nepal.

\section{Fund Flow and Allocation Mechanisms}

Collection of fund is important but more important is to use it effectively. Donors provide fund in basket but utilizing it timely and properly ensures its effectiveness.

\section{Decentralization of Aid Flow and Allocation Mechanism}

Decentralization brings the government closer to the stakeholders. This will contribute to increase people's participation in the governance process which engenders people's strong position in the decision making process. The aid flow mechanism in Nepal lacks this sort of approach. The fund flow mechanism in education is depicted in the following diagram. In the diagram, a long ad painstaking process is seen regarding the flow of funds reaching down to the school level. This is what the government has put in place.

Figure.3. The Funds Flow System

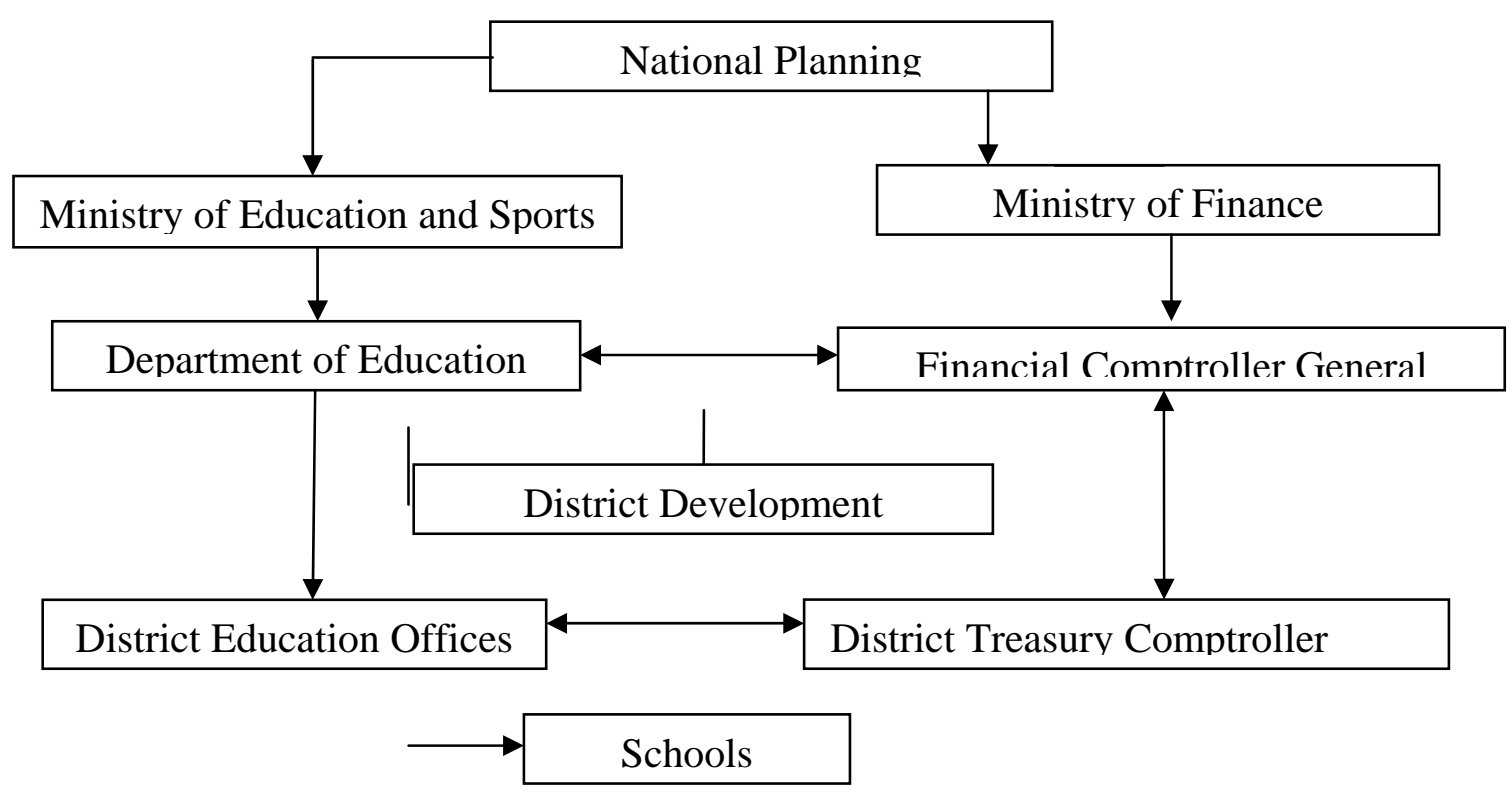


Source: DOE, 2010

Apart from this fund flow modality, teachers' salary is processed through the following way. In principle, teachers' salary is to be processed through the following approach:

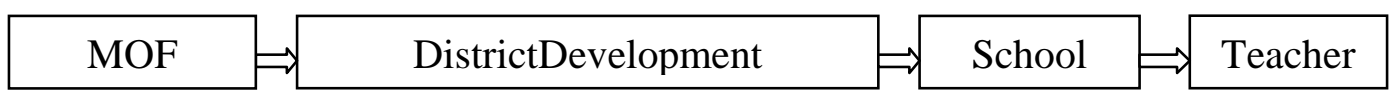

However, in practice, there are seven steps to be followed as shown in the following diagram.

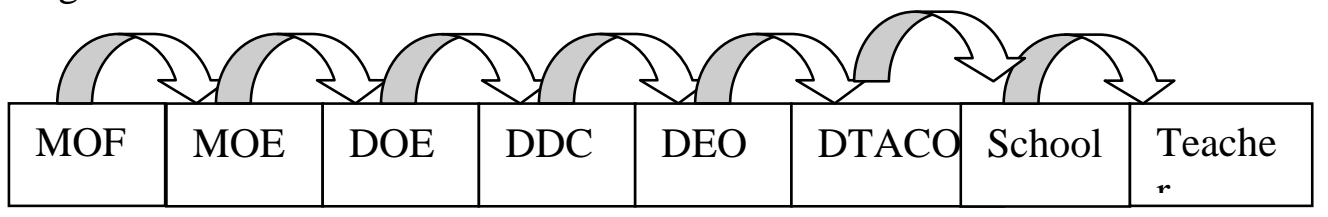

Fund flow for extra salary purposes is shown in the following diagram.

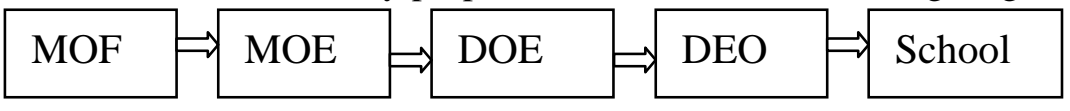

Looking at these fund flow approaches, they seem to be highly centralized. A centralized mechanism induces difficulties in running activities because the long process takes a long chunk of time and cost efficiency. Concerning this issue, most of the research participants suggested the need for decentralizing fund flow for better efficiency and increased effectiveness.

\section{Purpose-Based Funds-Flow within School System}

Purpose-based funds-flow within school system with mutual consensus among the school stakeholders is a reliance that pools the available resources to all key stakeholders who share a common financial goal. By doing this, the beneficiary groups also become involved in appropriate management of fund. With this approach in place, each and every member acts as a watch dog in the utilization of funds.

\section{Transparency and Accountability}

Transparency and accountability are equally crucial in the context of foreign aid whether the aid money has been utilized as per the mutually agreed terms and conditions or raises the issue of accountability. Transparency is concerned with the clarity of approaches adopted for aid utilization. A government official commented regarding the transparency and accountability of the foreign aid in education in Nepal.

\section{Monitoring and Evaluation Mechanism}

Monitoring and evaluation mechanisms are indispensable measures for proper allocation of resources which is pertinent in the education sector as well. They address accountability and transparency by gathering issues and processing the information on different aspects of the functioning of aid and identifying strategies for further improvement in the allocation of 
resources. The monitoring and evaluation mechanisms in Nepal regarding aid utilization is still ineffective which eventually may turn out to be a betrayal factor in achieving positive results of aid. In addition, the process of auditing that is required for effective and transparent monitoring and evaluation also needs to be accounted.

\section{Auditing}

Financial auditing is an official procedure of financial monitoring for maintaining financial discipline as well as for financial transparency and accountability. But financial audit alone is not enough for transparency and accountability. Hence, social and performance audits are also necessary. Role of social and performance audits is high in achieving aid effectiveness too.

Auditing can be considered as one of the most important mechanisms of monitoring and evaluation. A civil society member noted the best way of measuring effectiveness of aid either in qualitative or in quantitative side is auditing. By auditing, we simply understand financial audits but in fact financial audit is not sufficient. When we conduct social and performance audit, it shows the effectiveness more appropriately.

\section{Corruption Control}

It is a common understanding among all of us that corruption has spoiled Nepali bureaucracy and political system. The foreign aid context is not an exception. To control corruption, it is important to raise the level of critical awareness of the people. When people will raise questions and seek clarifications, chances for abusing aid will be reduced. In this way, the anti-corruption campaign should start from the people's end.

\section{Aid Governance}

Aid governance is crucial to ensure aid effectiveness. The nature of aid governance focuses basically on aid management, and utilization may vary according to contextual diversity. Participatory approach contributes to making more realistic decisions in aid administration.

\section{Management System}

A management system is an established structure for managing and constantly improving any program. A better management system, which is normally developed on the basis of shared vision and responsibility leads to achieve desired goals. It is more fruitful for benchmarking, sharing ideas, team work and working for high quality and efficiency.

\section{Aid Fungibility}

The aid becomes a substitute for covering budgeted program. Aid does not get utilized for the stipulated purpose, rather is used unscrupulously and thus resulting to be ineffective and fungible. 
Therefore, aid fungibility proves that the aid governance is going haywire. Another problem in aid governance is to explore to what extent we are letting the aid to make us dependable. Aid governance that ignored dependency factors will tend to create further dependency.

\section{Dependency vs. Sustainability Syndrome}

The question is not “will it help?” but “will it make us dependent?” This in fact has been one of the strongest criticisms of foreign aid that it makes the recipient country crippled and after a period, it starts to weaken the foundation of development because like the creepers, they root themselves in the very nerves of the base which gradually weakens them. The 'how long' of aid is never questioned because everyone is satisfied with the 'how much' of aid.

In fact, we are not clear about setting our destiny for meeting the need for sustainable education for all; we are being more dependent on others. It is really harmful in the long term. So, it is the need of the time to move away from dependency syndrome to a more sustainable one.

\section{Donors' Superiority Syndrome}

Donor's superiority syndrome means the hierarchy that is formed during the aid giving and receiving process where the donor acquires higher status and the recipient acquires lower one.

In terms of aiding to developing countries, donors have been dominant. They decide whether to aid country or not according to their convenience. They follow 'top-down' model for making decision. Decision thus is made by donors'sector in the suitable sector for the effective investment. Then they inform to the bureaucrats for their plan. The stakeholders are generally not invited for the decision making process.

\section{School Power}

School is a place where we provide education to people and it is power holding place for formal education. School power means when the school has the strength to govern its activities on its own and maintain the quality through this. However, if some amount of support is invested by the community, it motivates the community members to take interest in the project and keep checking on it. Community involvement in the school then tends to foster the strength of the school. In this way, when a school becomes the main player in this process, they become more engrossed in the holistic process of planning and decision making. This further strengthens their interest and commitment in gathering up internal as well as community resources and supports. The school power then becomes the tower to channelize and distribute the benefits, build relationship with the community and therefore, foster sustainability in educational arena. In this way, certain internal and external forces are preventing the school from functioning fairly and professionally, thereby driving out the power that a school should have. 


\section{Conclusion}

The result seems like aid is no more 'assistance' but an instrument to finance in education. Thus, the only efficient management of aid can omit the gap between development partners and receivers. It cannot be argued that aid has certainly picked up the pace of improvement in aid in primary education. Still, the effectiveness of the aid has become a very questionable prospect at present.

Aid quality and its effectiveness is the main agenda in educational aid today. To determine quality aid and utilize it effectively for needy and marginalized people is most debatable matter among recipient and development partner countries. Hence, the challenge for the government is to develop common perception and reality of aid effectiveness in education focusing on basic and primary sub-sector.

Government of Nepal is struggling to receive big volume of aid and claiming to utilize it more effectively. It is possible only with the harmonization of development partners. Contradictorily, local stakeholders, aid experts, educationalist and civil society members have big dissatisfaction of ineffective use of aid among government of Nepal and development partners. Quantitative progress is of course important but more important is to achieve qualitative progress. So, the researcher used EFA indicators, its targets and achievements during 2001-2015 to show quantitative as well as qualitative progress.

The research participants were able to map out a picture; representing situation, discussing setbacks, exploring possibilities and furthermore, providing analytical frameworks of aid in primary education of Nepal. The research participants' narratives helped build a link between aid in primary education and how it can foster development. Initially, the idea seemed far-fetched that aid in primary education would lead to any social and economic returns however, the discussed elements of aid and its use and the identification of the loopholes gave a different picture of how aid and primary education become two huge links to development in a country like Nepal.

\section{REFERENCES}

Acedo, C. (2009) Aid effectiveness in education. Prospects, 39, 107-108. doi: 10.1007/s11125009-9118-X

ADB. (2004)Nepal: Recent political and economic developments, and country operations. Manila: Author. Retrived from http//www.adb.org/.../Nepal/recent-political-economicdevelopments. pdf

Bermingham, D., Christensen, O. R., \& Mahn, T. C. (2009) Aid effectiveness in education: Why it matters. Prospects, 39, 129-145. doi: 10.1007/s11125-009-9120-3 
Berry, C. (2009) A framework for assessing the effectiveness of the delivery of education aid in fragile states. Journal of Education for International Development, 4 (1), 1-12.

Bhattarai, B. P. (2005). The effectiveness of foreign aid: A case study of Nepal. Unpublished Doctoral Thesis. University of Western Sydney, School of Economics and Finance. Sydney-Australia.

Bhattarai, B. P. (2009). Foreign aid and growth in Nepal: An emperical analysis. Journal of Developing Areas, 1-16.

Bourguignon, F., \& Leipziger, D. (2006). Aid growth and poverty reduction: Toward a new partnership model. Washington, DC: The WorldBank.

Dann, Z., \& Barclay, I. (2006). Complexity theory and knowledge management application. The Electronic Journal of Knowledge Management, 4(1), 11-20. Retrived from http//www.ejkm.com

Hudson, A. (2007). Beyond-aid policies and impacts: Why a developing country perspective is important. London: ODI.

Jandhyala, G. B. (2004). Foreign aid for education. International review for Education, 34 (3), 313-335.

Juarrero, A. (2006). Dynamics in action: Intentional behavior as a complex system. Retrieved May 21, 2010, from Explorations in Learning: http://secondlanguagewriting.com/explorations

/Archives/2006/Sep/iDynamicsinActionIntenti.html

Khadka, N. (2008). U.S. aid to Nepal in the cold war period: Lessons for the future. Retrieved June 25, 2008, from Questia: http://www.questia.com/

Michaelowa, K., \& Weber, A. (2008). Aid effectiveness in primary, secondary and tertiary education (Background paper prepared for the Education for All Global Monitoring Report 2008 Education for All by 2015: will we make it?). Paris:UNESCO.

Parnini, S. N. (2009). Public sector reform and good governance: The impact of foreign aid on Bangladesh. Journal of Asian and African Studies, 44 (5), 553-557. doi: 10.1177/0021909609338903

Powell, A. (2007). Tough love: The key to foreign aid effectiveness. Retrieved December 12, 2009, from Inter- American Development Bank: http://www.iadb.org/news/detail.cfm? language $=$ English\&id $=4050$

Serrat, O. (2009). Understanding complexity. Manila: Asian Development Bank.

Shah, A. (2009). Global issues. Retrieved December 16, 2009, from US and Foreign Aid Assiatance: $\quad$ http://www.globalissues.org/article/35/us-and-foreign-aid-assistance\# RichNationsAgreedatUNto07ofGNPToAid

Udenrigsministeriet. (2003). Evaluation Nepal: Joint government - Donor evaluation of basic and primary education programme II. Denmark: Udenrigsministeriet. Retrived from http://www.um.dk/Publikationer/Danida/ English/Evaluations/ EvalutionNepal2004 /index.asp 